\title{
Epidemiological investigation of traumatic upper extremity fractures in children who applied to emergency department
}

\section{Acil servise başvuran çocuklarda travmatik üst ekstremite kırıklarının epidemiyolojik incelenmesi}

\author{
Mehmet Esen, ${ }^{1}$ (1) Hilal Irmak Sapmaz ${ }^{2}$ \\ 'Department of Emergency Medicine, Tokat Gaziosmanpaşa University Faculty of Medicine, Tokat, Turkey \\ ${ }^{2}$ Department of Anatomy, Gaziosmanpaşa University Faculty of Medicine, Tokat, Turkey
}

\begin{abstract}
Introduction: Serious and potentially fatal multi-trauma in childhood can rarely be seen. However, each one of 5 children is exposed to minor trauma. Our aim is to reveal upper extremity traumas, trauma mechanisms and seasonal relationship in children under 18 years of age.

Methods: In this retrospective study, the files and graphs of 500 patients under 18 years old who applied to Tokat Gaziosmanpaşa University Medical Faculty Emergency Service after trauma were examined through Enlil and PACS system. 328 patients with upper extremity pathology were included in the study. These patients were analyzed according to different age groups $(0-4,5-8,9-12,13-17)$.

Results: 500 patients were screened and 328 patients $(65.6 \%)$ with upper extremity trauma were included. 109 (33.23\%) patients were female and 209 (66.77\%) patients were male. The most frequent $0-4$ year upper extremity traumas $(n=39)$ in girls were found to decrease with age. In boys, it was found that the upper extremity traumas increased with age, the most common age was 13-17 $(n=79)$. The distal radius fracture $(n=64)$ and distal humerus fracture $(n=61)$ were the most common in upper extremity traumas. The highest falling down in the etiology of 328 patients with upper extremity pathology ( $n=149,45.43 \%)$ was detected. It was determined that traumatic upper extremity pathologies were followed most in summer (36.58\%) followed by autumn, spring and winter respectively.

Discussion and Conclusion: Two-thirds of children under 18 years old who applied for trauma were admitted due to upper extremity trauma. It was found that fracture of the distal radius $(n=87)$ was the most $(33.85 \%)$ when the isolated radius fractures, bilateral forearm fractures, and upper extremity multiple fractures were evaluated together in children.
\end{abstract}

Keywords: Child; fracture; trauma; upper extremity.
Özet

Amaç: Çocukluk çağında ciddi ve potansiyel ölümcül multi travmalar nadir görülebilir. Ancak her 5 çocuktan biri minör travmaya maruz kalır. Bizim amacımı 18 yaş altı çocuklarda üst ekstremite travmalarını, travma mekanizmalarını ve mevsimsel ilişkisini ortaya koymaktır.

Gereç ve Yöntem: Retrospektif olarak planlanan bu çalışmada, Tokat Gaziosmanpaşa Üniversitesi Tıp Fakültesi Acil Servisi'ne travma sonrası başvuran 18 yaş altındaki 500 hastanın dosyaları ve grafileri, Enlil ve PACS sistemi üzerinden incelendi. Üst ekstremite patolojisi tespit ediIen 328 hasta çalışmaya dahil edildi. Bu hastalar farklı yaş grublarına göre (0-4,5-8,9-12,13-17) analiz edildi.

Bulgular: 500 hasta tarand, içerisinden üst ekstremite travması olan $328(\% 65,6)$ hasta alındı. $109(\% 33,23)$ hasta bayan, 209 $(\% 66,77)$ hasta erkekti. Kız çocuklarında en sık 0-4 yaş üst ekstremite travmaları $(n=39)$ saptanırken, yaşla beraber azaldığı tesbit edildi. Erkek çocuklarda ise yaşla beraber üst ekstremite travmalarının arttığı, en sık 13-17 yaşta ( $n=79)$ olduğu saptandı. Üst ekstremite travmalarında en sık distal radius kıığı $(n=64)$ ve distal humerus kırığı ( $n=61)$ saptandı. Üst ekstremite patolojisi olan 328 hastanın etyolojisinde en fazla düşme ( $n=149, \% 45,43)$ saptanmıştır. Travmaya bağlı üst ekstremite patolojilerinin en çok (\%36.58) yaz mevsiminde yaşandığı bunu sırasıyla sonbahar, ilkbahar ve kışın takip ettiği tespit edilmiş̧ir.

Sonuç: Travma nedeniyle başvuran 18 yaş altı çocukların 2/3'ü üst ekstremite travması nedeniyle başvurdu. Çocuklarda gerek izole radius kırıkları, gerek önkol çift kırıkları, gerek üst ekstremite çoklu kırıkları ile kırıklı çıkıkları birlikte değerlendirildiğinde en çok (\% 33.85) radius distal ucunun ( $n=87$ ) kırıldığı tespit edilmiştir.

Anahtar Sözcükler: Çocuk; kırık; travma; üst ekstremite. 
$C^{\prime}$ hildren and adolescents often use their upper extremity to explore their surroundings, to act independently, to participate in sports and a play event. For this reason, traumatic injuries of the hands and upper extremities are extremely common in all age groups. Trauma in children often causes extremity fractures. Before age seventeen, one-third of all children experience at least one bone fracture. ${ }^{[1]} \mathrm{A}$ fracture is detected in approximately $9 \%$ of children who have been treated with emergency trauma. ${ }^{[2]}$

The pediatric bone anatomy and physiology produces childspecific, age-specific forms of injury and conditions that make it difficult for emergency clinicians to know for certain. Compared to the adult bone, a child's bone has more porous, vascular, less dense and lower mineral content. This biomechanically imparts low energy absorption capability while producing low flexural modulus and low bending strength in the pelvis. Flexibility and high absorbance properties prevent the spread of broken bone in children and reduce the incidence of fragmented fractures, more difficult fractures than adults, and special types of fractures such as plastic deformation and greenstick fractures. As the age increases, the bending strength and elasticity module of the bone increase, while the energy absorption decreases. ${ }^{[3]}$

The periosteum is thick and has a high vascular structure as well as excessive bleeding of the child's bone resulting in easy boiling in children and very little union. ${ }^{[4-6]}$

Locations of fractures and the causes of fractures are different according to age groups. The main causes are falling, traffic accidents and beatings in children, sports and traffic accidents in young people, traffic and work accidents in middle ages, and falling, traffic accidents and osteoporotic fractures in older ages. In children, fractures of the elbow and supracondylar humerus, especially radius and ulna fractures, are the most frequently fractured bones. At young and middle ages, radius distally, femur and tibia are the most broken regions. In older ages, femoral neck, trochanter major and minor region, proximal humerus, and radius distally are the bone fragments with the most fractures. ${ }^{[7-10]}$

Five major causes of death in children (ages 1-14) are drowning, falling from the top, burns, traffic accidents and violence. These causes account for almost $66 \%$ of the fatal injuries in children. ${ }^{[1]}$ Multiple traumas are rare in children and constitute only $5 \%$ of all serious injuries. ${ }^{[12]}$ However, this may be seen in many minor injuries as well as serious and potentially fatal injuries and is treated in emergency departments. The published literature mainly focuses on traumatic serious injuries in children, ${ }^{[12,13]}$ with only a few studies addressing minor injuries in children. ${ }^{[14-16]}$

The aim of this study is to examine the etiology and pathophysiology of fractures specific to children and adolescents, and the common injuries in the upper extremities.

\section{Materials and Method}

In this study, files and graphs of 500 patients under 17 years

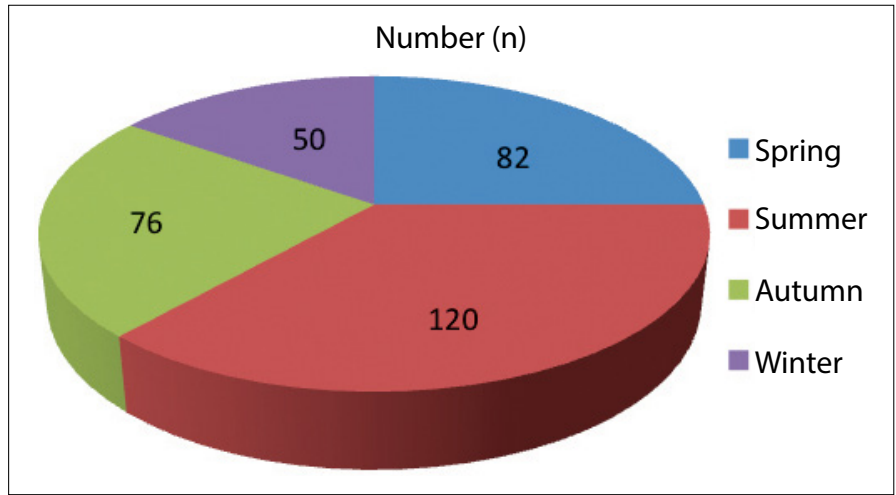

Figure 1. Seasonal distribution of traumatic upper extremity pathologies.

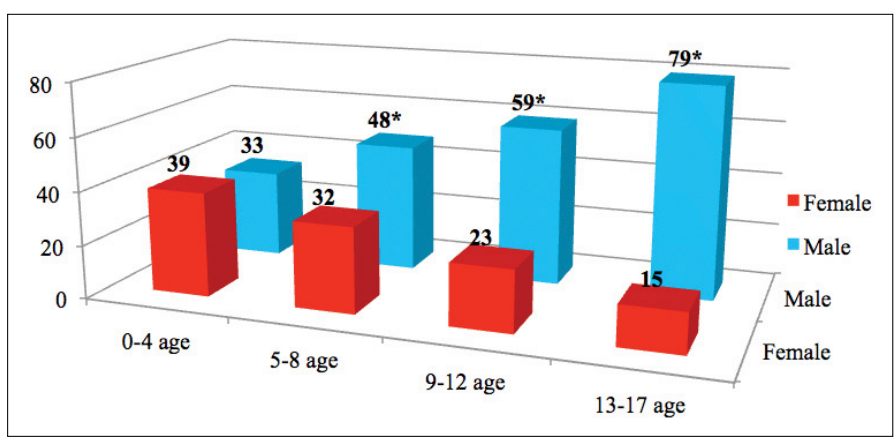

Figure 2. Distribution of traumatic upper extremity pathologies according to age and gender. The upper extremity pathologies seen in 5-8, 9-12 and 13-17 age groups were found to be more frequent in males (Chi-square ${ }^{*} p=0.001$ ).

old who applied for trauma to Tokat Gaziosmanpaşa University Medical Faculty Emergency Department between January 2015 and December 2017 were reviewed retrospectively through Enlil and PACS system. 328 patients with upper extremity pathology were included in the study.

Inclusion criteria:

- Under 18 years of age

- Upper extremity pathology

- No history of neuromuscular disease

- Has an X-ray examination

Non-participation criteria:

- Over 17 years old

- Neuromuscular disease is a storyteller

- Burns

- Superficial injuries

\section{Statistics}

SPSS 20 package program was used in the statistical evaluation of the boys and girls who applied for the emergency service with upper extremity trauma.

Chi-square test was performed to compare all age groups. $p$ $<0.05$ was considered significant. 


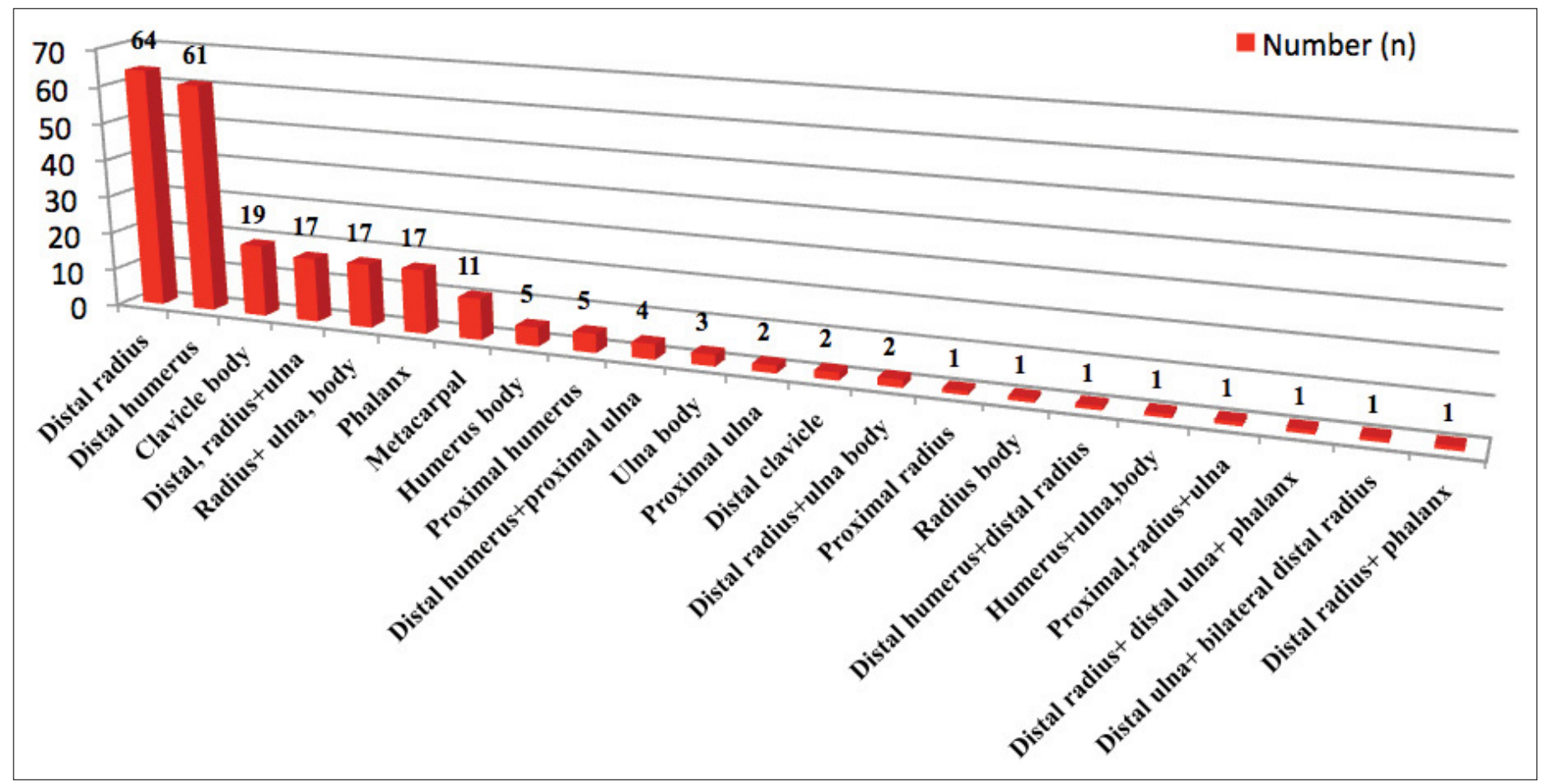

Figure 3. Bone fractures according to the traumatic upper extremity.

\section{Results}

328 patients with upper extremity pathology, 219 (66.76\%) were male and 109 (33.23\%) were female. Of the 328 patients with upper extremity pathology, 257 had upper extremity fractures. The rate of right (129 fractures) and left (128 fractures) extremities were found to be approximately equal.

It was determined that traumatic upper extremity pathologies were mostly occurred in summer (36.58\%) followed by autumn, spring and winter respectively (Figure 1).

When grouping according to age, it was found that the traumas related to the upper extremity increased as boys aged (45.83\%) in the $0-4$ age group and $84.04 \%$ in the $13-17$ age group) and decreased in the reverse age group in the girls ( $54.1 \%$ in the $0-4$ age group versus $13-1715.95 \%$ in the age group) (Figure 2).

Fractures involving a single bite of the upper extremity in children were mostly seen at the radius $(34.12 \%)$ followed by humerus (26.19\%) and clavicula (8.3\%) fractures. Radius and ulna were found to fracture together in $15.47 \%$ of upper extremity fractures (Figure 3).

In 328 cases of trauma involving the upper extremity in children, 30 were found with dislocations, broken bump, amputation and foreign body (Figure 4).

Pathologies of upper extremities in 328 patients falling in the etiology come at the forefront. A total of 268 patients who fell due to falls fell from a height of 37 (Figure 5).

In lesser proportions, ball strikes, stiff surface collision, collision with a friend, withdrawal from the arm by another, and traffic accidents are among the reasons (Figure 6).

It was determined that fracture of the distal radius of the ra-

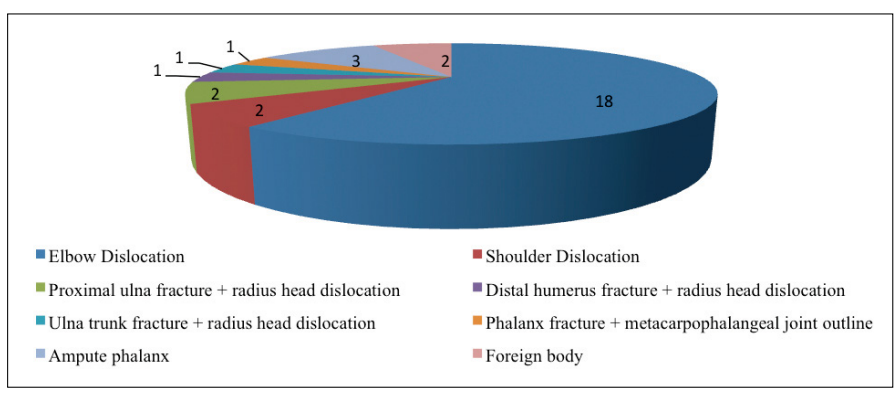

Figure 4. Dislocations in upper extremity traumas and other pathologies.

dius $(n=87)$ was the most broken $(33.85 \%)$ when isolated radial fractures, bilateral fractures of the forearm, and multiple fractures of the upper extremity together with the fractured dislocations were evaluated in children (Figure 7. radius distal tip fracture).

When forearm bone fractures were assessed in children, it was determined that there were 24 body fractures (Figure 8 fork fracture of the forearm bones).

$85.71 \%$ of total 77 humerus fractures in children are distal humerus fractures, mainly suprachondias and condyles (Figure 9 , humerus distal tip fracture).

\section{Discussion}

We are exposed to many traumas while continuing our daily life. As a result of these traumas, bone fractures occur. There are differences among the causes of bone fracture in children and adults. The frequency of fractures varies depending on age, season, cultural and social factors. ${ }^{[17]}$ Increasing participa- 


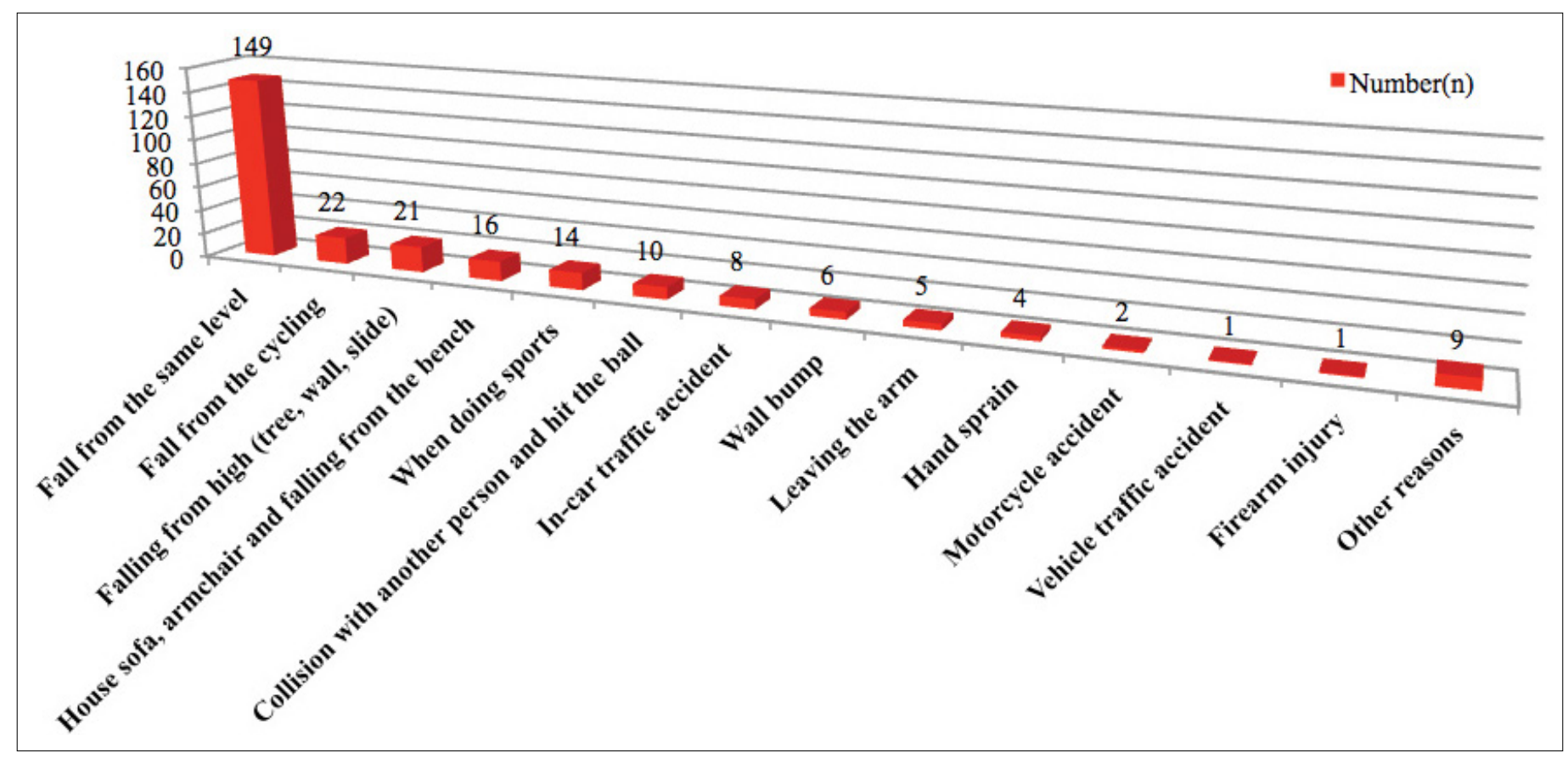

Figure 5. Bone fractures according to the traumatic upper extremity.

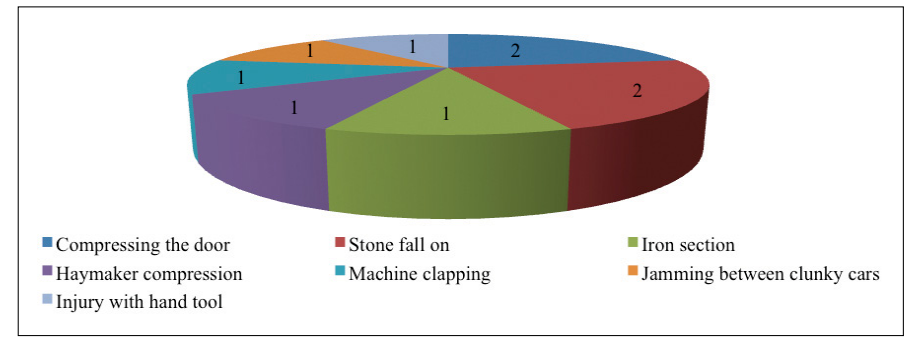

Figure 6. Other reasons for upper extremity trauma.

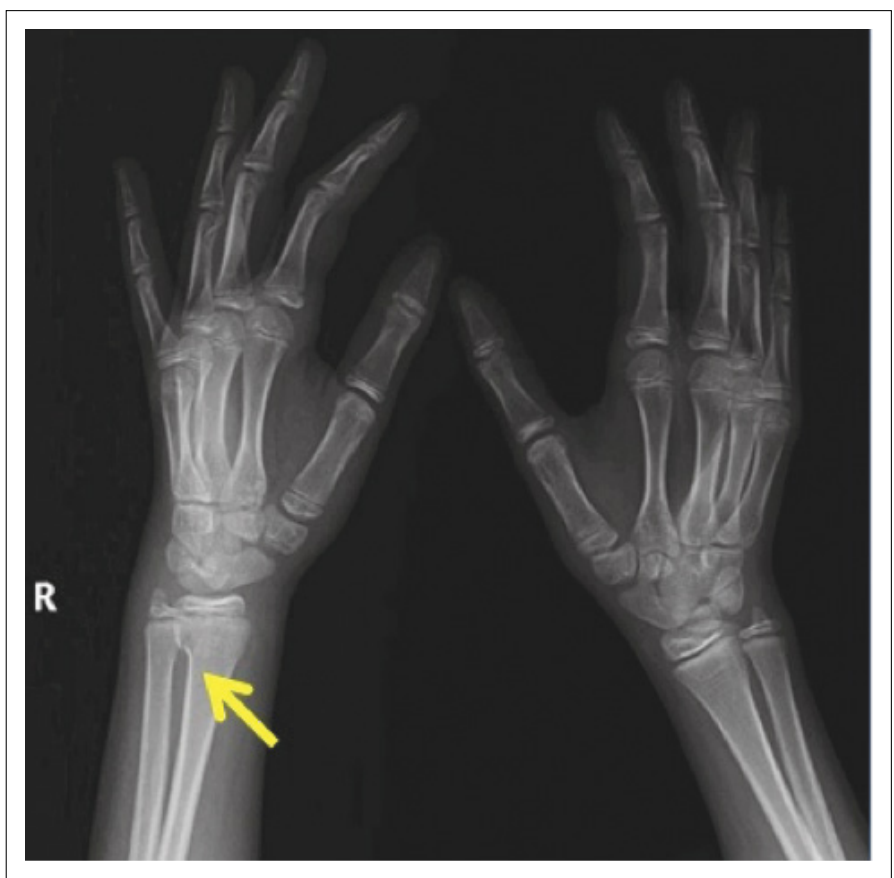

Figure 7. Radius distal tip fracture.

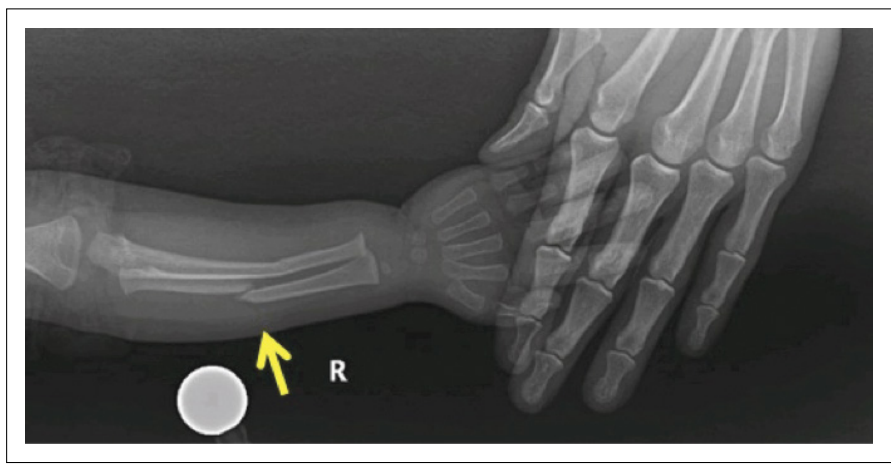

Figure 8. Forearm bones body trunk.

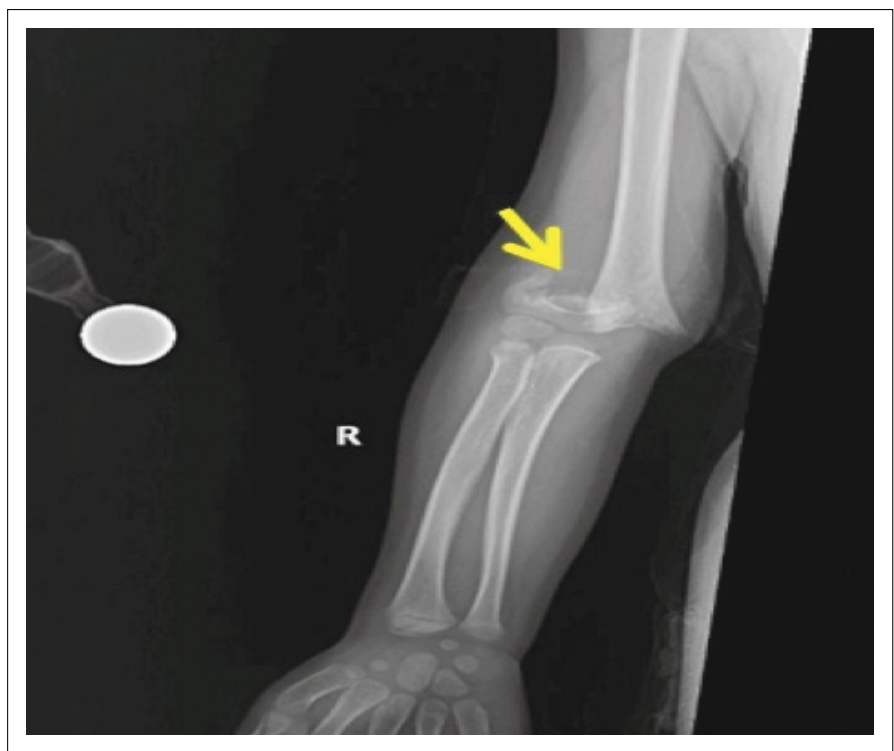

Figure 9. Humerus distal tip fracture. 
tion of parents in the working life in recent years, increased traffic accidents due to the increase in the number of vehicles, inadequacy of playgrounds compared to the growing population, and poor nutrition have led to an increase in bone fragility rates in children ${ }^{[18]}$ As a result, one-third of all children before 17 years old experience at least one bone fracture. ${ }^{[1]}$

In a retrospective study between 1990 and 2008, McKenzie et al. found that children who applied with emergency service $(32.1 \%)$ had fractures and dislocations due to dropping from the skateboarding. $89 \%$ of the injured were male and $11 \%$ were female. It has been reported that the majority of children hospitalized are between 11 and 14 years of age as compared to the other groups. According to age groups, it was determined that upper extremity injuries were seen in children 5-10 years and 11-14 years old with the rates of $42.3 \%$ and $49.5 \%$, respectively. The injuries at home are in the first place, followed by injuries on the road and sports. When assessed according to the body regions, the upper extremity injuries are followed by lower extremity, face, head-neck and trunk injuries in the decreasing sequence. ${ }^{[19]}$ In our study, 219 (66.76\%) of the 328 patients were male and 109 (33.23\%) were female. Upper extremity fracture was detected in 328 (65.6\%) of 500 trauma cases. The upper extremity fracture was detected most frequently in boys between 13-17 years of age and in girls between 0-4 years old most frequently. The group with the highest hospitalization rate was the 13-17 age group.

Falls are one of the main causes of trauma-related hospitalizations and the 0- to 18-year-old children are a client to emergency departments. ${ }^{[20-23]}$ The analysis of factors influencing upper extremity fractures revealed a relatively high incidence of injuries for children over 3 years old and injuries due to falls. ${ }^{[24,25]}$ In our study, the most common cause of upper extremity fracture was the fall of 149 cases (58\%) of 257 cases.

Rennie et al., in their retrospective studies, reported that 2168 children who came to the hospital due to trauma within one year and $61 \%$ of them were male and most of them were fractured (82.2\%). It is stated that the most common cause is a fall in the level of the bed (less than 1 meter), and that half of the upper extremity fractures formed in this way break the distal radius and ulna. These are followed by phalanges, metacarpal bones, humerus distal and clavicula fractures, respectively. The clavicula in the first year, the distal humerus and radius in the second and fourth years, and the distal radius in the 5-11 and 12-16 age groups are the most frequently seen anatomical locations. In this study, it was determined that there were more fractures in children during the seasonally hot months. The forms of trauma that caused the fractures were reported as falling from the top, blunt trauma, high-level falls, sports injuries, traffic accidents, and buckling. ${ }^{[26]}$ In a study conducted by Karl et al., most distal radius fractures were detected under the age of 18 years. ${ }^{[27]}$ In our study, fractures of the distal radius $(n=64)$ and distal humerus $(n=61)$ were observed most frequently. In our study, upper extremity traumas were seen most frequently in summer $(n=120,36.6 \%)$. The clavicle is the most common fracture (90\%) at birth and $5-15 \%$ of all childhood fractures. ${ }^{[28,29]}$ In our study, the fracture of the clavicle was detected as $8.17 \%$ of the fractures.

Rubin et al. analyzed the children and adults hospitalized because of the traffic accidents, between 1997 and 2013; they examined the files of 103,465 patients and 30,378 of them were children. In taxi, motorcycle and bicycle accidents, the highest radius, ulna and finger fractures occurred in children. In the pedestrian accidents, it was determined that the humerus was broken most. ${ }^{[30]}$ In our study, the upper extremity traumas were found to be $10.33 \%$ and the most common radius and humerus fractures were found.

Zararsız et al. reported that the upper extremity fractures were the most common in the child age group among the patients who applied for emergency trauma within one year. The fractured bones are often referred to as radius, humerus, and ulna, respectively. ${ }^{[31]}$ In our study, fractures of radius $(n=106)$, humerus ( $n=77)$ and ulna $(n=49)$ were similarly detected.

Fractures of the proximal humerus, which account for $80 \%$ of the longitudinal growth of the humerus, are not common in children. These are $0.5-3.5 \%$ of all childhood fractures. ${ }^{[32]}$ In our study, 5 (2.12\%) cases were found.

Humerus body fractures constitute approximately $2.5 \%$ of childhood fractures and are second in the incidence of birth fractures after clavicle. It is quite frequent in pathological fractures due to unicameral bone cyst except for trauma. ${ }^{[33]}$ In a child younger than three years of age with a spiral fracture pattern, abuse may be the issue. ${ }^{[34]}$ In our study, humerus fracture was found in 5 (\% 2.12) cases.

Supracondylar humerus fractures, which are usually seen between 3 and 10 years of age and more common in men, account for $16 \%$ of all childhood fractures and $60 \%$ of childhood elbow fractures. ${ }^{[35,36]}$ In our study, $26,16 \%$ cases were supracondylar humerus fracture.

Forearm fractures, which account for approximately $40-50 \%$ of child's long bone fractures, represent the fracture at any level of the radius and/or ulna. ${ }^{[37]}$ As the upper half of the forearm is well protected by the muscles, distal displaced fractures are more frequent. In our study, 111 (46.84\%) cases were found to have forearm fractures.

In children younger than 16 years, $3 \%$ of all fractures are distal radiostas. Of all fizeal fractures, $30-46 \%$ are distal radiologists and $86 \%$ of these fractures occur in children 9 years of age. ${ }^{[38,39]}$ In our study, 87 (36.7\%) cases of distal radius fracture were detected in accordance with the literature.

In children, elbow dislocations are less common than adults. Most of the dislocations are towards the posterolateral; lateral, medial and anterior dislocations are less common. Some fractures may accompany the dislocation. The medial epicondyle is the most common fracture in children. ${ }^{[40-42]}$ In our study, the elbow protrusion $(n=18)$ was observed in the dislocations of the upper extremity and it was observed that the fracture was 
accompanied in the 4 cases of dislocation. One of them had a medial epicondyle fracture.

\section{Conclusion}

Our study was conducted in Tokat, located in the Middle Black Sea Region, to investigate upper extremity traumas in children. In the present study, we found that upper extremity traumas (65.6\%) in children who applied to the emergency service with trauma and $72.25 \%(n=237)$ of them had fractures in the upper extremity. These rates are quite high. Therefore, to demonstrate the potential hazards to children according to their psychomotor development in adolescence stage, to take the necessary measures, it is necessary to pay attention to balanced nutrition. Arranging training for children's parents and child caregivers will reduce child trauma and bone fractures. In this way, we can protect our children and help to protect the health resources of our country.

Conflict of Interest: There are no relevant conflicts of interest to disclose.

\section{References}

1. Cooper C, Dennison EM, Leufkens HG, Bishop N, van Staa TP. Epidemiology of childhood fractures in britain: a study using the general practice research database. J Bone Miner Res 2004;19:1976-81.

2. Spady DW, Saunders DL, Schopflocher DP, Svenson LW. Patterns of injury in children: a population-based approach. Pediatrics 2004;113:522-9.

3. Currey JD, Butler G. The mechanical properties of bone tissue in children. J Bone Joint Surg Am 1975;57:810--4.

4. Einhorn TA. The cell and molecular biology of fracture healing. Clin Orthop Relat Res 1998:S7-21.

5. Jacobsen FS. Periosteum: its relation to pediatric fractures. J Pediatr Orthop B 1997;6:84-90.

6. Wallace ME, Hoffman EB. Remodelling of angular deformity after femoral shaft fractures in children. J Bone Joint Surg $\mathrm{Br}$ 1992;7:765-9.

7. Kalender O, Gurcu T, Reisoglu A, Agus H. The frequency and distribution of fractures in children presenting to the emergency service [Article in Turkish]. Acta Orthop Traumatol Turc 2006;40:3847.

8. Taviloğlu K, Aydin A, Cuhali BD, Demiralp T, Güloğlu R, Ertekin C. The evaluation of the suitability of our cases for referral to a level I trauma center [Article in Turkish]. Ulus Travma Derg 2001;7:14650.

9. Ritsema TS, Kelen GD, Pronovost PJ, Pham JC. The national trend in quality of emergency department pain management for long bone fractures. Acad Emerg Med 2007;14:163-9.

10. Hadjidakis DJ, Kokkinakis EP, Sfakianakis ME, Raptis SA. Bone density patterns after normal and premature menopause. Maturitas 2003;44:279-86.

11. Euro Safe. Injuries in the European Union. Summary on in- jury statistics fort he years 2012-14. Available at: http://www. bridge-health.eu/sites/default/files/EuropeSafe_Master_R4_SinglePage_12102016\%20\%281\%29.pdf. Accessed Sep 9, 2018.

12. Auner B, Marzi I. Pediatric multiple trauma [Article in German]. Chirurg 2014;85:451-61.

13. Meier R, Krettek C, Grimme K, Regel G, Remmers D, Harwood P, et al. The multiply injured child. Clin Orthop Relat Res 2005:127-31.

14. Albert M, McCaig LF. Injury-related emergency department visits by children and adolescents: United States, 2009-2010. NCHS Data Brief 2014:1-8.

15. Ruffing T, Danko S, Danko T, Henzler T, Winkler H. Injuries in children and adolescents in emergency services [Article in German]. Dtsch Arztebl 2015;119:654.

16. Snyder CW, Muensterer OJ, Sacco F, Safford SD. Paediatric trauma on the Last Frontier: an 11-year review of injury mechanisms, high-risk injury patterns and outcomes in Alaskan children. Int J Circumpolar Health 2014;73:25066.

17. Wilkins KE. The incidence of fractures in children. In: Rockwood CA, Wilkins KE, Beaty JH. Fractures in children. Vol. III. 4th ed. Philadelphia: Lippincott-Raven, 1996. p. 3-17.

18. Kalender Ö, Gürcü T, Reisoğlu A, Ağuş H. The frequency and distribution of fractures in children presenting to the emergency service [Article in Turkish]. Acta Orthop Traumatol Turc 2006;40:3847.

19. McKenzie LB, Fletcher E, Nelson NG, Roberts KJ, Klein EG. Epidemiology of skateboarding-related injuries sustained by children and adolescents 5-19 years of age and treated in US emergency departments: 1990 through 2008. Inj Epidemiol 2016;3:10.

20. Benoit R, Watts DD, Dwyer K, Kaufmann C, Fakhry S. Windows 99: a source of suburban pediatric trauma. J Trauma 2000;49:477-82.

21. Keogh S, Gray JS, Kirk CJ, Coats TJ, Wilson AW. Children falling from a height in London. Inj Prev 1996;2:188-91.

22. Ong ME, Ooi SB, Manning PG. A review of 2,517 childhood injuries seen in a Singapore emergency department in 1999-mechanisms and injury prevention suggestions. Singapore Med J 2003;44:129.

23. Lallier M, Bouchard S, St-Vil D, Dupont J, Tucci M. Falls from heights among children: a retrospective review. J Pediatr Surg 1999;34:1060-3.

24. Joeris A, Lutz N, Wicki B, Slongo T, Audigé L. An epidemiological evalua $\neg$ tion of pediatric long bone fractures - a retrospective cohort study of 2716 patients from two Swiss tertiary pediatric hospitals. BMC Pediatr 2014;14:314.

25. Mathison DJ, Agrawal D. An update on the epidemiology of pediatric frac $\neg$ tures. Pediatr Emerg Care 2010;26:594-603.

26. Rennie L, Court-Brown CM, Mok JY, Beattie TF. The epidemiology of fractures in children. Injury 2007;38:913-22.

27. Karl JW, Olson PR, Rosenwasser MP. The Epidemiology of Upper Extremity Fractures in the United States, 2009. J Orthop Trauma 2015;29:e242-4.

28. England SP, Sundberg S. Management of common pediatric fractures. Pediatr Clin North Am 1996;43:991-1012.

29. Nordqvist A, Petersson C. The incidence of fractures of the clavicle. Clin Orthop Relat Res 1994:127-32.

30. Rubin G, Peleg K, Givon A, Rozen N. Upper extremity open frac- 
tures in hospitalized road traffic accident patients: adult versus pediatric cases. J Orthop Surg Res 2017;12:157.

31. Zararsız I, Kaya E, Savaş N, Meydan S, Davran S, Tutanç M, et al. The Distrubition and Frequency of Fracture Cases in Patients Presented To Emergency Department of Mustafa Kemal University Tayfur Ata Sökmen Medical Faculty [Article in Turkish]. F.Ü.Sağ.Bil. Tıp Derg 2009;23:155-8.

32. Pahlavan S, Baldwin KD, Pandya NK, Namdari S, Hosalkar H. Proximal humerus fractures in the pediatric population: a systematic review. J Child Orthop 2011;5:187-94.

33. Garg S, Dobbs MB, Schoenecker PL, Luhmann SJ, Gordon JE. Surgical treatment of traumatic pediatric humeral diaphyseal fractures with titanium elastic nails. J Child Orthop 2009;3:121-7.

34. Shaw BA, Murphy KM, Shaw A, Oppenheim WL, Myracle MR. Humerus shaft fractures in young children: accident or abuse? J Pediatr Orthop 1997;17:293-7.

35. Kumar V, Singh A. Fracture supracondylar humerus: A Review. J Clin Diagn Res 2016;10:RE01-6.

36. Skaggs D, Pershad J. Pediatric elbow trauma. Pediatr Emerg Care
1997;13:425-34.

37. Rodríguez-Merchán EC. Pediatric fractures of the forearm. Clin Orthop Relat Res 2005:65-72.

38. Randsborg PH, Gulbrandsen P, Saltytė Benth J, Sivertsen EA, Hammer OL, Fuglesang HF, et al. Fractures in children: epidemiology and activity-specific fracture rates. J Bone Joint Surg Am 2013;95:e42.

39. Huntley SR, Summers SH, Stricker SJ. Salter-Harris type-IV displaced distal radius fracture in a 5-year-old. J Pediatr Orthop B 2016;25:170-3.

40. Herring JA. Upper extremity injuries. In: Tachdjian MO, editor. Pediatric Orthopedics. Vol III. 3rd ed. Philadelphia: WB Saunders Comp; 2002. p. 2191-4.

41. Wilkins KE. Fractures and dislocations of the elbow region. In: Rockwood CA, Wilkins KE, Richard EK, editors. Fractures in children. Vol III. 1st ed. Philadelphia: Lippincott Comp; 1984. p. 53053.

42. Papandrea R, Waters PM. Posttraumatic reconstruction of the elbow in the pediatric patient. Clin Orthop 2000;370:115-26. 